This item was submitted to Loughborough's Research Repository by the author.

Items in Figshare are protected by copyright, with all rights reserved, unless otherwise indicated.

\title{
Disaster risk reduction or disaster risk production: the role of building regulations in mainstreaming DRR
}

PLEASE CITE THE PUBLISHED VERSION

http://dx.doi.org/10.1016/j.ijdrr.2015.03.002

\section{PUBLISHER}

(C) Elsevier

VERSION

AM (Accepted Manuscript)

\section{PUBLISHER STATEMENT}

This work is made available according to the conditions of the Creative Commons Attribution-NonCommercialNoDerivatives 4.0 International (CC BY-NC-ND 4.0) licence. Full details of this licence are available at: https://creativecommons.org/licenses/by-nc-nd/4.0/

\section{LICENCE}

CC BY-NC-ND 4.0

\section{REPOSITORY RECORD}

Chmutina, Ksenia, and Lee S. Bosher. 2019. "Disaster Risk Reduction or Disaster Risk Production: The Role of Building Regulations in Mainstreaming DRR”. figshare. https://hdl.handle.net/2134/17349. 


\title{
DISASTER RISK REDUCTION OR DISASTER RISK PRODUCTION: THE ROLE OF BUILDING REGULATIONS IN MAINSTREAMING DRR
}

\author{
Ksenia Chmutina $^{\mathrm{a}}$ and Lee Bosher ${ }^{\mathrm{b}}$ \\ ${ }^{\text {a }}$ Corresponding author. School of Civil and Building Engineering, Loughborough \\ University, Loughborough, Leicestershire, LE11 3TU, UK. Email: k.chmutina@lboro.ac.uk; \\ tel: +44(0)1509 228526 \\ ${ }^{\mathrm{b}}$ School of Civil and Building Engineering, Loughborough University, Loughborough, \\ Leicestershire, LE11 3TU, UK. Email: 1.bosher@lboro.ac.uk
}

\begin{abstract}
Whilst it has not experienced any major disasters in recent years, Barbados is prone to a number of hazards and has the highest proportion of its urban produced capital at risk in the Caribbean due largely to the island's high population density. One of the main challenges that Barbados faces in coping with the possible impacts of natural hazards is the enhancement of construction practices, and consequently, the quality of building stock. This is however hard to achieve due to the lack of enforced building codes. Using a qualitative case study methodology, that includes semi-structured interviews with a broad range of public and private stakeholders in Barbados, this paper aims to explore how the lack of such codes affects the mainstreaming of disaster risk reduction across the island. This paper demonstrates that whilst the awareness of the hazards among the population is high, the willingness to proactively deal with those hazards is low due to general complacency. The case of Barbados, despite good intentions and limited resources, is a good example of why it is essential to improve communication of DRR principles to a wider set of stakeholders including the general population and the construction sector. Such activities may positively influence the uptake of the best practices despite the lack of regulations.
\end{abstract}

Keywords: Disaster risk reduction; Barbados; building regulations

\section{Introduction}

Caribbean countries are ranked amongst the top 50 riskiest places in the world when it comes to the number of disasters per capita and per square kilometre (Rasmussen, 2006; Collymore, 2011). The Caribbean is one of the most disaster-prone regions in the world. More than 400 hazards afflicted the region between 1950 and 2012, including 267 tropical storms and hurricanes and 113 floods; on average there is a 14 percent probability that a Caribbean country will be hit by a tropical storm in any given year (Laframboise and Acevedo, 2014).

Barbados is the most easterly of all the Caribbean countries with an area of $430 \mathrm{~km}^{2}$ and a population of 280,000 people (excluding the $1.1 \mathrm{~m}$ tourists who visit the island each year) (Worldmark Encyclopaedia of Nations, 2007) (Figure 1). 


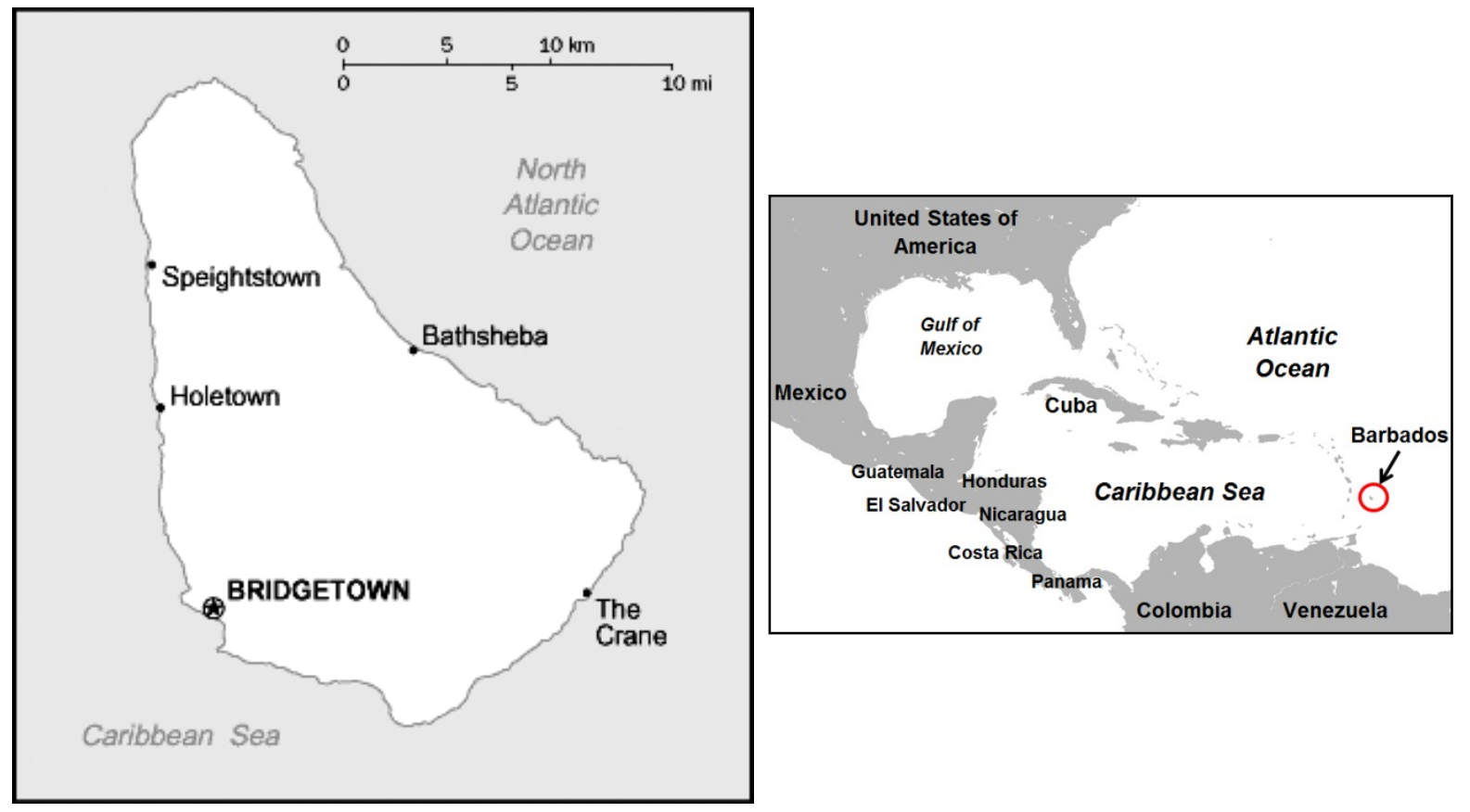

Figure 1 Map of Barbados (Source: Adapted from Wikimedia)

The island's climate is tropical with a rainy hurricane season between June and October. Despite the relatively small size, the country has good economic and social development indicators and is classed as having 'very high human development' (UNDP, 2013). However, due to its geographic location, Barbados is susceptible to a number of natural hazards, including hurricanes, floods, coastal erosion, landslides, and earthquakes (The Government of Barbados, 2005; Prevatt et al., 2010; Pulwarty et al., 2010). The island's vulnerability is high not only due to its geographical location and climatic conditions but also by such factors as (CDERA, 2004):

- Intensive use of small land space;

- Upstream dumping of solid waste in watercourses/ gullies;

- $\quad$ Large percentage of impervious surface; and

- Inadequate drainage exacerbated by the continuing change in land use and landform.

According to United Nation's 'Global Assessment Report on Disaster Risk Reduction 2013' (UN 2013), Barbados has the highest proportion of its urban produced capital at risk (followed by Puerto Rico) in the Caribbean. The extreme density of its population (664 people $/ \mathrm{km}^{2}$ ) increases the vulnerability of the island to natural hazards (Sarmiento and Hoberman, 2011).

Barbados is susceptible to hurricanes due to its proximity to the North Atlantic hurricane belt; however, the country has not been affected by a major hurricane since 1955 , when hurricane Janet destroyed almost all of the housing stock (Griffin, 2007). Tropical storm Tomas in October 2010 was a 'wake-up' call and a reminder of the importance of disaster 
preparedness: public utilities were interrupted in some parts of the island for up to a week, and homes, as well as large areas of vegetation, were severely damaged (Caribsave, 2012).

The risk of flooding - in particular pluvial flooding - is considered by some experts to be higher than that of wind damage (Collymore, 1992; Hinds and Spence, 2006; UN, 2013).

Pluvial flooding is particularly disruptive as it may last for a number of days thus interrupting transport and posing health risks; whilst the direct losses may not be high, the indirect losses to the built environment and related infrastructure can be significant (UN, 2013).

While not as recurrent as storms, hurricanes and flooding, there are other natural hazards that pose a potential threat to Barbados, as highlighted in the various academic literature and national and international reports (e.g. Collymore, 2011; Caribsave, 2012). In the last decade the evidence of soil erosion has been increasing, particularly in the Scotland District, which is prone to landslides due to geological and topographical characteristics. Earthquakes also pose a serious long-term threat to the island (Collymore, 2011). An earth tremor was experienced on 29th of November 2007, caused by a powerful earthquake in Dominica. Although the tremor did not cause major disruption in Barbados, some houses were damaged in the parishes of St George and St Philip, and the mobile network system was out of service for about an hour.

While Barbados is not a volcanic island, it is under the threat of tsunami events, which could be caused by the active submarine volcano 'Kick'em Jenny', located $9 \mathrm{~km}$ northeast of Grenada, and about 260 km south-west from Barbados (CDERA, 2003).

It has already been acknowledged that one of the main challenges Barbados faces in reducing its vulnerability to natural hazards is the enhancement of construction practices, and consequently, the quality of building stock (Chmutina and Bosher, 2014). To date this has been hard to achieve due to the lack of enforced building codes and a low level of awareness of the vulnerabilities among the population. The most recent GAR 2015 has acknowledged that Disaster Risk Reduction (DRR) activities need to move away from an approach that has been constrained within disciplinary siloes dominated by emergency management and civil protection practitioners (UN 2015). A broader range of important stakeholders should take on responsibility for DRR activities; this however will require suitable levels of training and practical support. Arguably, the general public - the most important stakeholder (whether they are aware of it or not) should be central to such holistic approach. The aim of this paper is twofold:

- to explore how the lack of enforces building codes affect the mainstreaming of DRR, and

- to understand whether the enforcement of such codes can increase public awareness of vulnerabilities. 


\section{Methodology}

In order to understand the relationship between the lack of enforced building codes and mainstreaming of DRR, a case study approach was applied: it is the most appropriate research method when questions whether and how are asked (Yin, 1994; Eisenhardt, 1989). The conclusions taken from case studies can be applied to the development of new theories and concepts, and the revision of existing ones (Yin, 1994), and to present a 'comprehensive research design, with a multi-disciplinary character and a large number of factors to be considered' (de Weerd-Nederhof, 2001).

The key gaps discussed in this paper have been identified by Chmutina and Bosher (2014) and suggested for further investigation - which this paper sets out to achieve. Extensive web and literature research was initially conducted to identify relevant secondary data. An extensive content analysis of the 'Draft of the Building Code' was also performed based on the identification of sections relevant to the natural hazards prevalent in Barbados.

Three site visits were then conducted in 2013 and 2014 as this helped to obtain valuable insights (Lofland and Lofland, 1995) when discussing ongoing development projects and to understand the environment and the context in which the projects are taking place. Semistructured interviews with a broad range of stakeholders that are (or should be) involved in DRR were conducted. The interviewees were selected through some trusteed sources that work in the construction industry in Barbados; after that the interviewees assisting in making contact with other relevant stakeholders. The interviewees were representing stakeholders generally involved in the construction and disaster/emergency management sectors. Both private and public stakeholders were interviewed to enable a better understanding of governmental and business points of view. Overall, 15 semi-structured in-depth interviews with key stakeholders from a range of professional backgrounds were conducted:

- Two architects working in the private construction sector

- Two developers working in the private housing property development sector

- Two contractors working in the private sector;

- Risk manager working in a utility company;

- Emergency manager working in the public sector (government department);

- Engineer working in a private construction company;

- Urban planner working in the private construction sector;

- Fire and Rescue service officer, working in the national emergency service;

- Two rescue officers working in the national defence service;

- Technical Officer (Building Regulations) working in the public sector;

- Coastal manager working in the public sector (government department)

Each interview was approximately 60 minutes in duration, covering the following aspects (that were deemed relevant areas of inquiry based upon the work of Chmutina \& Bosher 2014): main hazards, stakeholders' engagement in DRR, policy and regulatory framework for DRR, and experiences of overall preparedness of Barbados to disasters. The aim of the interviews was to gain first-hand information regarding the decision-making process and the implementation of DRR measures, as well as the role of the stakeholder in DRR and their 
engagement with the general public. The interviews were recorded and thematically analysed. Thematic analysis was chosen due to the complexity and richness of the dataset and the need for a flexible analytical process to provide structure (Howitt and Cramer, 2011).

In order to understand how vulnerable the housing stock is, a small online survey ${ }^{1}$ was carried out. Its aim was not to generalise the overall vulnerability of the building stock but to provide some empirical information. 50 respondents representing different demographics and living in the different parts of the island were asked about the impacts and exposure to natural hazard. As described by Zhou et al. (2003), individual perceptions to natural hazards and disaster risk is influenced by individual differences including age, education, occupation, gender etc., as well as by indirect experiences such as knowledge about disasters, media stories, environment of habitation and so on. Whilst individual differences have been gathered (the sample is diverse in terms of gender, occupation, area of living and age), it is difficult (if not impossible) to take into account the indirect impacts, thus the results of the survey are to an extent skewed. However, the aim of the survey was not to demonstrate statistical precision of the results, but rather provide empirical insights into this discussion. After distributing 120 online $^{2}$ surveys using Bristol Online Survey software, 50 responses were returned. The survey consisted of 25 questions divided into 3 sections (Personal Information, Perception of Hazards and their effects on dwelling, and Awareness of risks and risk reduction options), with the majority of the questions being multiple choice. The responses have been analysed using Excel, however since all of the responses were given in 'textual' rather than numerical form, a qualitative coding method was used (SSC, 2001): this allowed for the frequencies of different types of response being counted and/ or crosstabulated. Due to the relatively low number of responses $(0.02 \%$ of the total population of the island), it is acknowledged that the insights from this study are merely indicative and not statistically significant.

\section{Current situation in Barbados}

\section{1 'Disaster management' and social awareness of disaster risk in Barbados}

Until recently, 'Disaster management' in Barbados was based on a 1940s model developed mainly to provide relief to the general population after an emergency event. It comprised an institutional framework where traditional response agencies (fire and rescue service and police) were brought under the central coordination of a permanent secretariat once a disaster had struck (CDERA, 2004). The shift from response and relief to prevention and mitigation was made in 2007, when the Emergency Management Act 2006 introduced the Department of Emergency Management (DEM) that replaced the existing system (The Government of Barbados, 2006).

The original 1940s Organisation for Hurricane Relief was not integrated into planning for disaster preparedness, although public warnings were issued before the onset of a possible

\footnotetext{
${ }^{1} 50$ respondents representing different demographics and living in the different parts of the island were asked about the impacts and exposure to natural hazards.

${ }^{2}$ The survey was created using Bristol Online Survey Tool: http://www.survey.bris.ac.uk/
} 
hurricane. In 1978 the organization was renamed the Central Emergency Relief Secretariat which provided administrative support and coordination to the wider disaster management system in Barbados. Over the years, the Organisation was required to expand the scope of its responsibility to respond to other emergencies such as flooding and landslides, as well as man-made threats such as oil spills, industrial fires, aircraft crashes and large scale public service vehicle accidents (DEM, 2014). The newly established DEM is responsible for the development and implementation of the Emergency Management Programme and for the coordination of emergency management activities. It is also currently developing a national Comprehensive Disaster Risk Management (DRM) Programme that will cover natural hazards and man-made threats and all stages of DRM including DRR. The overview of the current National Emergency Management System is presented in Figure 2.

\section{National Emergency Management System}

\section{Department of Emergency Management}

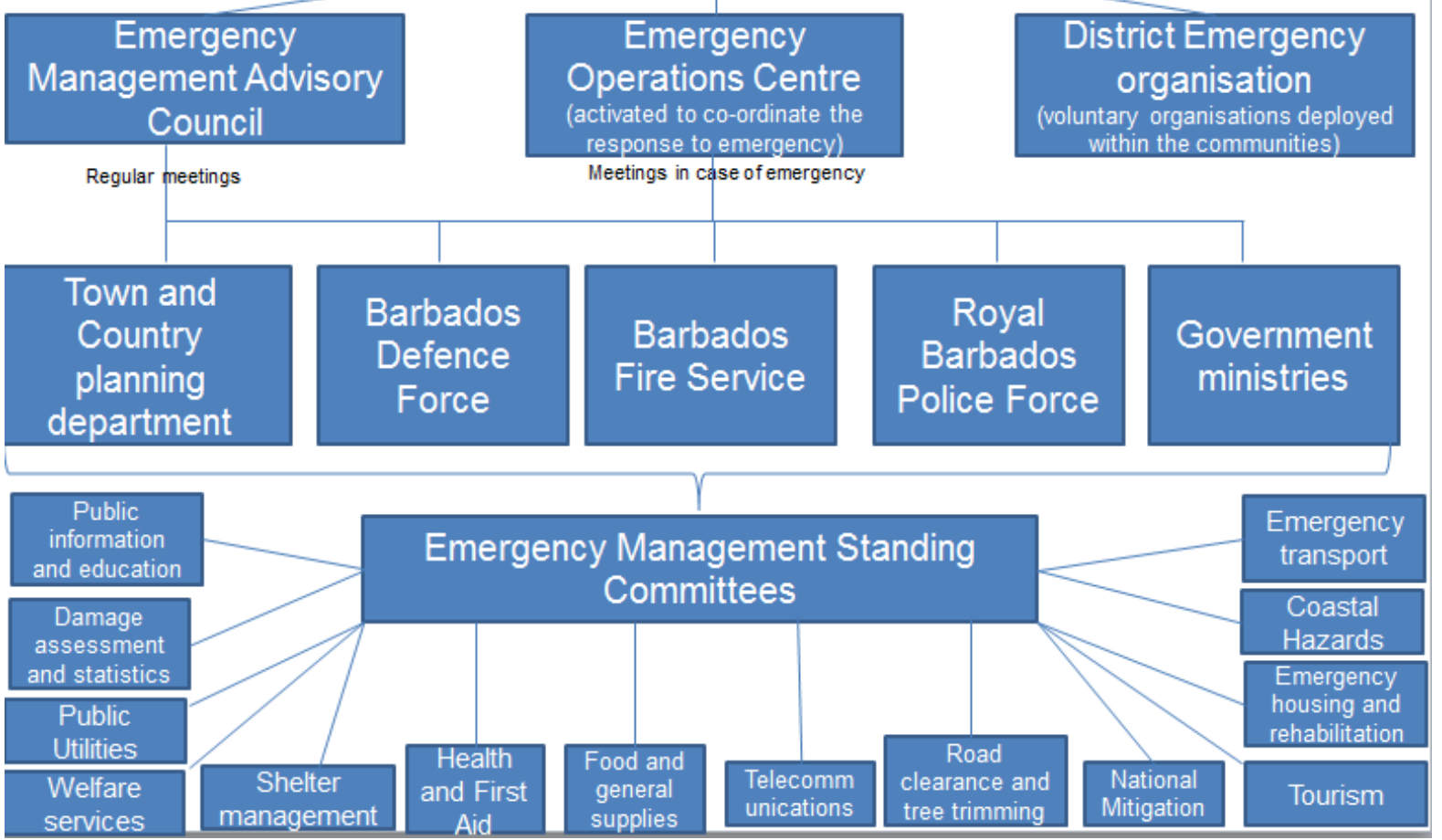

Figure 2: Barbados National Emergency Management System

It is also responsible for reporting on progress regarding the implementation of DRR activities, as Barbados signed the Hyogo framework for Action. Table 1 summarises levels of progress achieved with respect to the implementation of the HFA's five priorities for action. 
Table 1Summary of the progress achieved in implementation of HFA priority areas (selective areas, adapted from Thomas, 2013)

\begin{tabular}{|c|c|c|c|}
\hline $\begin{array}{l}\text { HFA priority } \\
\text { area }\end{array}$ & Core indicator & $\begin{array}{l}\text { Progress } \\
\text { achieved }\end{array}$ & Main challenges \\
\hline \multirow{4}{*}{$\begin{array}{l}\text { Ensure that } \\
\text { disaster risk } \\
\text { reduction is a } \\
\text { national and } \\
\text { local priority } \\
\text { with a strong } \\
\text { institutional } \\
\text { basis for } \\
\text { implementation }\end{array}$} & $\begin{array}{l}\text { National policy and legal framework with } \\
\text { decentralised responsibilities and capacities at all } \\
\text { levels. }\end{array}$ & 4 & $\begin{array}{l}\text { Policies and strategy are not regularly updated; } \\
\text { Lack of multi-stakeholder engagement; } \\
\text { Lack of inter-ministerial consultation; } \\
\text { Lack of capacity to conduct risk assessment }\end{array}$ \\
\hline & $\begin{array}{l}\text { Dedicated and adequate resources at all } \\
\text { administrative levels }\end{array}$ & 4 & $\begin{array}{l}\text { Restricted access to financing. } \\
\text { DRR is low on a priority list. } \\
\text { Lack of adequate support of all aspects of the DRR }\end{array}$ \\
\hline & Community Participation and decentralisation & 4 & $\begin{array}{l}\text { Lack of understanding of the areas where greater involvement of the community } \\
\text { would be beneficial. }\end{array}$ \\
\hline & Functioning national multi-sectoral platform & 4 & $\begin{array}{l}\text { Lack of human resource capacity within the DEM to meet the needs of all } \\
\text { stakeholders }\end{array}$ \\
\hline \multirow{4}{*}{$\begin{array}{l}\text { Identify, assess } \\
\text { and monitor } \\
\text { disaster risks } \\
\text { and enhance } \\
\text { early warning }\end{array}$} & $\begin{array}{l}\text { National and local risk assessments are available } \\
\text { and include risk assessments for key sectors. }\end{array}$ & 4 & $\begin{array}{l}\text { Lack of enforcement; } \\
\text { Lack of adequate incorporation of socio-economic data }\end{array}$ \\
\hline & $\begin{array}{l}\text { Systems are in place to monitor, archive and } \\
\text { disseminate data on key hazards \& vulnerabilities }\end{array}$ & 4 & $\begin{array}{l}\text { Disaster loss data is not yet mainstreamed into scientific and financial data streams } \\
\text { Lack of capacity }\end{array}$ \\
\hline & $\begin{array}{l}\text { Early warning systems are in place for all major } \\
\text { hazards }\end{array}$ & 4 & $\begin{array}{l}\text { Lack of system maintenance and training } \\
\text { Limited financial resources } \\
\text { Lack of public awareness about some of the hazards (e.g. earthquake) }\end{array}$ \\
\hline & $\begin{array}{l}\text { National and local risk assessments take account } \\
\text { of regional risks }\end{array}$ & 4 & Lack of capacity in the DEM \\
\hline \multirow{2}{*}{$\begin{array}{l}\text { Use knowledge, } \\
\text { innovation and } \\
\text { education to } \\
\text { build a culture } \\
\text { of safety and } \\
\text { resilience } \\
\text { at all levels }\end{array}$} & $\begin{array}{l}\text { Relevant information on disasters is available and } \\
\text { accessible at all levels, to all stakeholders }\end{array}$ & 3 & $\begin{array}{l}\text { Lack of information systems integration to ensure access and sharing } \\
\text { Lack of data and information sharing } \\
\text { Slow flow of information; } \\
\text { Slow update of communication technology } \\
\text { Lack of public access to information }\end{array}$ \\
\hline & $\begin{array}{l}\text { School curricula, education material and relevant } \\
\text { trainings include DRR }\end{array}$ & 4 & $\begin{array}{l}\text { Slow uptake; } \\
\text { Lack of champions }\end{array}$ \\
\hline
\end{tabular}




\begin{tabular}{|c|c|c|c|}
\hline & $\begin{array}{l}\text { Research methods and tools for multi-risk } \\
\text { assessments and cost benefit analysis are } \\
\text { developed and strengthened }\end{array}$ & 3 & Lack of links between scientists and practitioners \\
\hline & $\begin{array}{l}\text { Countrywide public awareness strategy exists to } \\
\text { stimulate a culture of disaster resilience }\end{array}$ & 5 & None \\
\hline \multirow{6}{*}{$\begin{array}{l}\text { Reduce the } \\
\text { underlying risk } \\
\text { factors }\end{array}$} & $\begin{array}{l}\text { DRR is an integral objective of environment } \\
\text { related policies and plans }\end{array}$ & 4 & $\begin{array}{l}\text { The broad range of climate change issues has not been generally understood by the } \\
\text { majority of the DRR stakeholders }\end{array}$ \\
\hline & $\begin{array}{l}\text { Social development policies and plans are being } \\
\text { implemented to reduce the vulnerability of } \\
\text { population }\end{array}$ & 4 & $\begin{array}{l}\text { Lack of access to financial and other resources } \\
\text { Homeless are not considered }\end{array}$ \\
\hline & $\begin{array}{l}\text { Economic and productive sectorial policies and } \\
\text { plans have been implemented to reduce the } \\
\text { vulnerability of economic activities }\end{array}$ & 3 & $\begin{array}{l}\text { Lack of promotion of the economic incentives to the wider population in a sustained } \\
\text { way }\end{array}$ \\
\hline & $\begin{array}{l}\text { Planning and management of human settlements } \\
\text { incorporate DRR elements }\end{array}$ & 3 & $\begin{array}{l}\text { Lack of political will to remove the population (e.g. squatters) from the vulnerable } \\
\text { areas; } \\
\text { Approvals of planning permissions for building in high risk zones }\end{array}$ \\
\hline & $\begin{array}{l}\text { DRR measures are integrated into post disaster } \\
\text { recovery and rehabilitation }\end{array}$ & 4 & $\begin{array}{l}\text { Lack of capacity; } \\
\text { Lack of a policing mechanism to ensure that the mitigation measures become } \\
\text { mandatory }\end{array}$ \\
\hline & $\begin{array}{l}\text { Procedures are in place to assess the disaster risk } \\
\text { impacts of major development projects }\end{array}$ & 3 & Lack of enforced building regulations \\
\hline \multirow{4}{*}{$\begin{array}{l}\text { Strengthen } \\
\text { disaster } \\
\text { preparedness for } \\
\text { effective } \\
\text { response at all } \\
\text { levels }\end{array}$} & $\begin{array}{l}\text { Strong policy, technical and institutional } \\
\text { capacities and mechanisms for DRM }\end{array}$ & 4 & $\begin{array}{l}\text { Lack of disaster preparedness in in-land zones ; } \\
\text { Lack of frequent simulation exercises and drills }\end{array}$ \\
\hline & $\begin{array}{l}\text { Disaster preparedness plans and contingency } \\
\text { plans are in place at all administrative levels, and } \\
\text { regular training drills and rehearsals are held }\end{array}$ & 4 & $\begin{array}{l}\text { Frequent personnel changes; } \\
\text { Lack of financial resources }\end{array}$ \\
\hline & $\begin{array}{l}\text { Financial reserves and contingency mechanisms } \\
\text { are in place to support effective response and } \\
\text { recovery when required }\end{array}$ & 4 & $\begin{array}{l}\text { Lack of access to finance; } \\
\text { Slow bureaucratic procedures }\end{array}$ \\
\hline & $\begin{array}{l}\text { Procedures are in place to exchange relevant } \\
\text { information during hazard events and disasters, } \\
\text { and to undertake post-event reviews }\end{array}$ & 5 & Significant lapse in the review process \\
\hline
\end{tabular}


One of the main responsibilities of the DEM is raising awareness amongst the general population. DEM uses mass media, social media, public lectures, exhibitions, open days and videos as well as brochures and publications to reach all segments of the population. The DEM has also been partnering with the public and private sector in using their systems and resources to raise the awareness (DEM, 2013): for example, the month of June is annually announced as a DRR month when in partnership with various organisations (e.g. Barbados Light and Power utility in 2012, and insurance companies in 2013), the DEM organises various events to increase the awareness and raise the interest in disaster risk before the start of a hurricane season in August/September. The general consensus is that the public's awareness is high, as they are provided with detailed and comprehensive information that can be used to prepare household plans. However, as it has been noted in Chmutina and Bosher (2014) that the absence of a major disaster/emergency event in recent decades has made the general Barbados public complacent (an observation that will be discussed later in this paper).

\subsection{Existing building stock in Barbados}

Primarily, the population of Barbados lives along the south-east, south and west coasts of the island. According to the latest Barbados Census (BSS, 2010), the majority of the population lives in concrete block separate houses built before 1991 (see Figures 3 to 5 for more information and Figure 6 for an example of the housing stock).

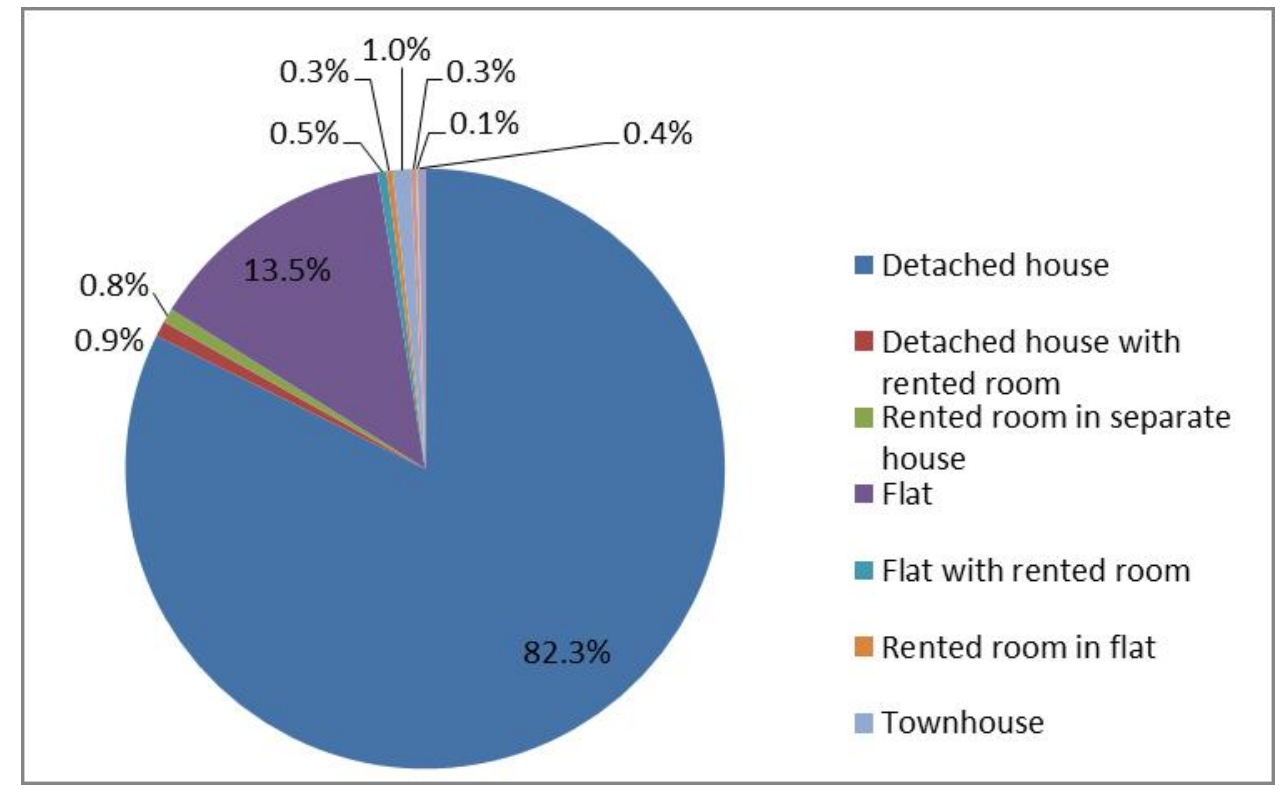

Figure 3: Type of dwelling (source: BSS, 2010) 


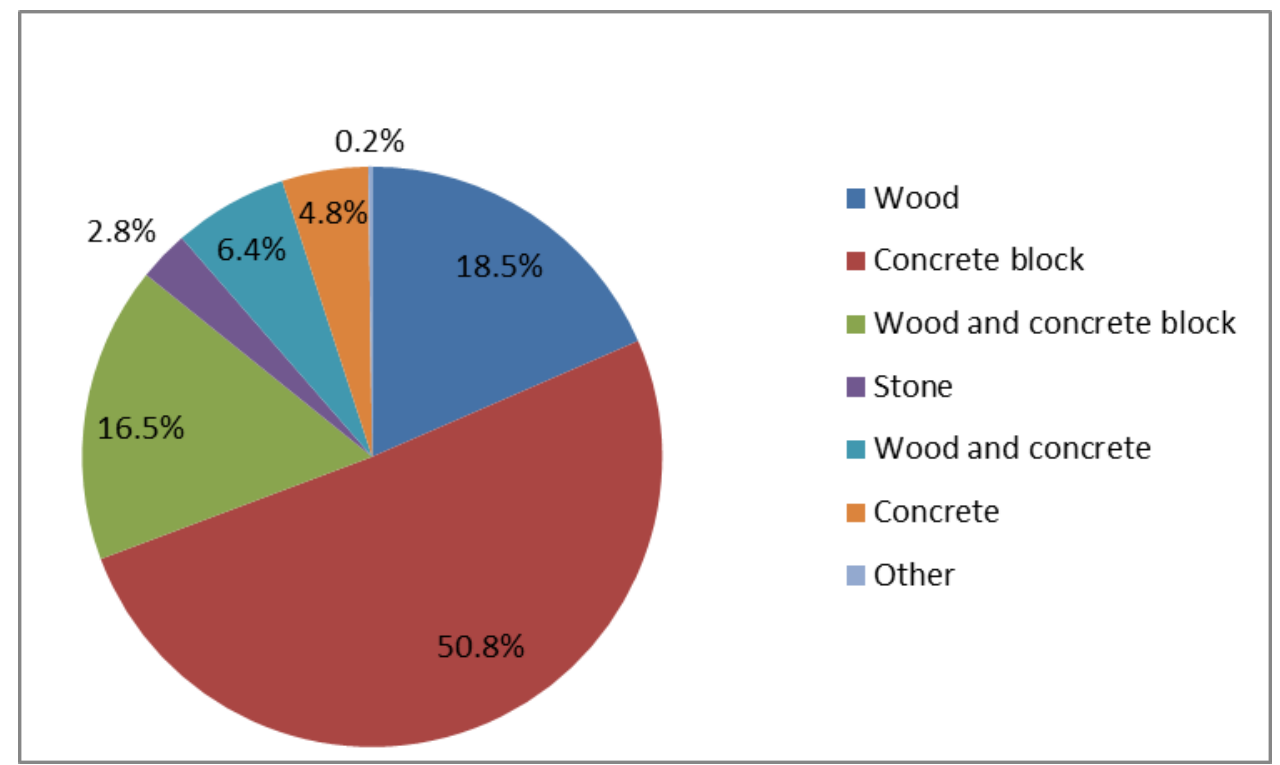

Figure 4: Material of outer wall (source: BSS, 2010)

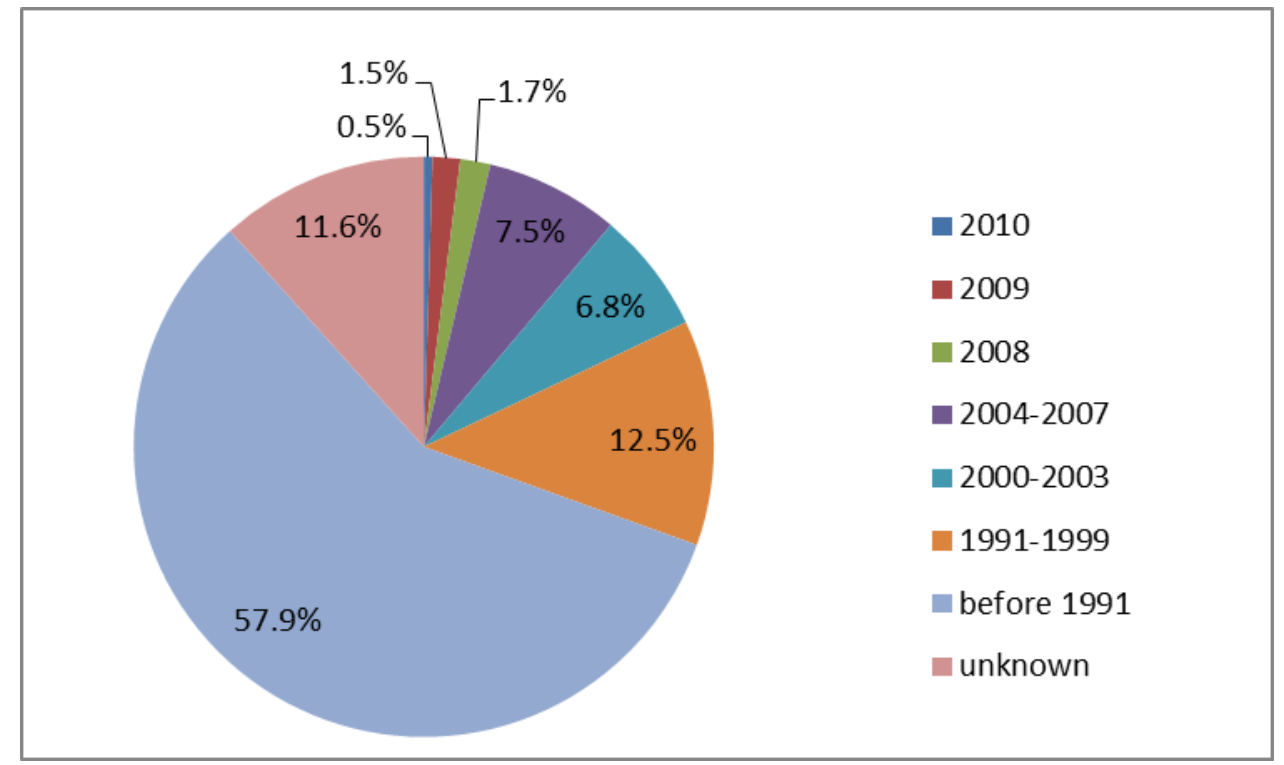

Figure 5: Year of construction (Source: BSS, 2010)

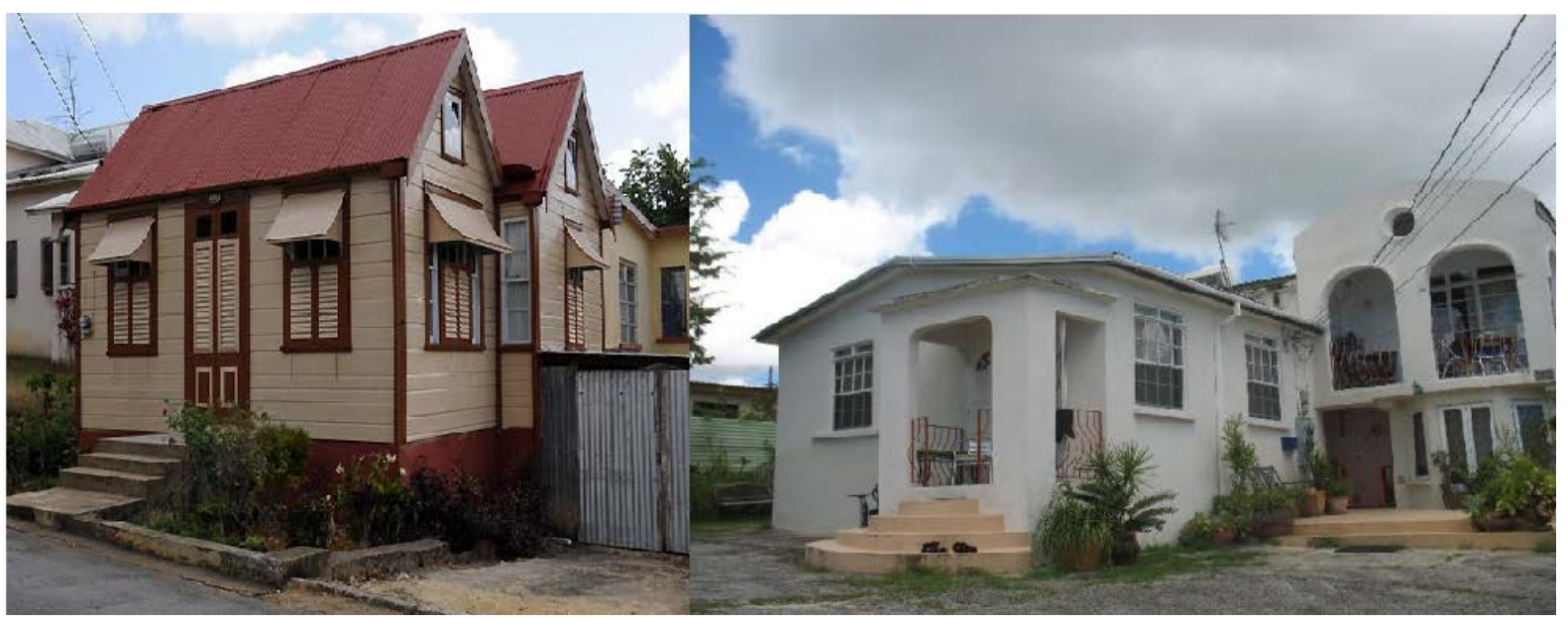

Figure 6: Examples of the houses in Barbados (author's images) 
One of the main issues with the existing DRM system in Barbados is that housing policy does not address the problem of natural hazards, and not enough attention has been paid to the vulnerability of the housing stock. This appears to be the case because DRM legislation is disjointed and is covered by various poorly integrated sections of policy and legislation. The main factors that make existing housing stock vulnerable are (CDERA, 2004):

- Vulnerable groups of people, particularly squatters;

- A large percentage of wooden houses (as demonstrated in previous section) that are vulnerable to hurricanes, storms and flooding;

- A particular heritage (not only historical but also sentimental) value of the wooden building stock, thus making it hard to upgrade or replace with modern designs;

- $\quad$ Large number of housing in the coastal zone;

- Inadequate enforcement of the building codes for residential developments, which comprise over $60 \%$ of Barbados total building stock.

Housing in the coastal zones is covered by the 1998 Coastal Zone Management and Strategy Plan, however, whilst the Plan deals with issues such as setbacks based on the storm surge potential (30m from the high water), it does not cover specific treatment of natural hazards. This point was mentioned in one of the interviews conducted during the data collection as an issue that is being addressed by the Coastal Zone Management Unit which together with the DEM is developing a new comprehensive DRM plan that will be more focused on risk assessment and institutional capacity enhancement.

High vulnerability of the building stock can be explained by the fact that there is no Building Code, and, whilst the draft exists, the Code has no legal power to incentivise people to follow its regulations when building a dwelling; thus arguably discouraging the safest types of building designs (Chmutina and Bosher, 2014).

\subsection{Barbados building code}

A key objective of any building code is life safety; this is why it is important to make sure that each building code is context specific. The earliest known written (and rather draconian) building code is the Code of Hammurabi, in ancient Mesopotamia, dating back to 1772BC; it states that "If a builder builds a house for someone, and does not construct it properly, and the house which he built falls in and kills its owner, then that builder shall be put to death" (King, 2014).

The Barbados National Building Code was introduced to the Parliament in 1993; since then its draft has only been updated and edited once - in 2013 - but the Code has not yet been legally bound and thus enforced. ${ }^{3}$ The code establishes various technical requirements and standards governing the design and construction of buildings in Barbados, and addresses issues relating to structural sufficiency and durability, fire safety, health and amenity. The

\footnotetext{
${ }^{3}$ The revised Code has been under the review of a Technical Committee since 2012.
} 
Draft of the Building Code does not affect the operation of any law concerning the use of public land, buildings, structures or roads (Organisation of American States, 2011). The code emphasises the importance of addressing the effects of climate change on the country, and 'takes into account the climate and geological conditions of Barbados, especially the nature of the Caribbean environment and the region's susceptibility to hurricanes and earthquakes' (BNSI, 2013: 23). It consists of 18 parts, and is based on the Scottish Executive Technical Standard and the UK Building Regulations. However, whilst based on the international standards, it focuses on local forms of construction such as the 'chattel house' (traditionally a small moveable wooden house). The public authority that will be responsible for the enforcement of the building regulations once it becomes mandatory is Building Standard Authority. ${ }^{4}$ The Building Standard Authority will be required to submit a list of building permit applications on a weekly basis to a range of agencies including the Fire Service Department, the public authorities responsible for environmental protection, water distribution, waterways and drainage, physical development planning, electrical engineering, Factory Inspectorate and Land Taxation.

The Code covers (to an extent) some natural hazards: hurricanes and storms, floods and earthquakes. However, flooding is the only hazard that receives a dedicated section (Part 2, section A-2); the Code also provides detailed information on moisture prevention, and waste water and surface drainage. Hurricanes and earthquakes are only briefly mentioned in the section on Structure in the context of the installation of windows and hurricane shutters, and roof coverage (which should resist the uplift from a minimum wind speed of $208 \mathrm{~km} / \mathrm{h}$ ), and the calculation of the earthquake loads.

\subsection{Vulnerability of the building stock}

As mentioned previously, In order to understand how vulnerable the housing stock is, a small online survey was carried out. Out of 50 respondents, 17 have been affected by hurricane/storm and/or flooding (Table 2).

The respondents were also asked about the safety of their property. Out of 15 respondents who own their property, nine of them built it themselves. The majority of the dwellings are 20 to 40 years old, and thus when built were not guided by the draft of the Building Code which was introduced in 1993 (there was no Building Code before than). It is impossible to identify whether newer property meets the Building Code, as despite its introduction - and as already been mentioned - the Code is not legally enforced and thus remains voluntary. 30 of the respondents believe that their dwellings are 'very safe' or 'pretty safe'. However some of the respondents admit that the safety of their dwelling will largely depend on the type of hazard; in particular the dwellings are not prepared for earthquakes and tsunamis. The respondents were also asked about the drivers that would encourage them to improve the safety of the house: unsurprisingly, nearly all of the respondents would like to see some kind

\footnotetext{
${ }^{4}$ This is however is not stated in the current draft of the Code; instead 'public authority' is used, as Building Standard Authority currently does not exist (sourced from information gathered during the interviews).
} 
of financial incentives; however access to information was also mentioned as being important. Stricter building regulations were also seen as an important driver, and will be discussed next.

Table 2 Damage created to survey respondents' dwellings by natural hazards

\begin{tabular}{|l|c|l|l|}
\hline Parish & $\begin{array}{l}\text { Number of houses } \\
\text { affected }\end{array}$ & Type of hazard & Type of damage \\
\hline Christchurch & 1 out of 8 & Storm & $\begin{array}{l}\text { Loss of water supply, } \\
\text { Loss of electricity, } \\
\text { Damage to the land around the dwelling }\end{array}$ \\
\hline St Andrew & 1 out of 2 & Storm & $\begin{array}{l}\text { Loss of water supply, } \\
\text { Loss of electricity }\end{array}$ \\
\hline St George & 2 out of 3 & Storm & $\begin{array}{l}\text { Loss of water supply, } \\
\text { Loss of electricity }\end{array}$ \\
\hline St James & 2 out of 10 & Storm; flood & $\begin{array}{l}\text { Loss of electricity, } \\
\text { Damage to the land around the dwelling, } \\
\text { Severe damage to the house }\end{array}$ \\
\hline St Michael & 2 out of 16 & Storm & $\begin{array}{l}\text { Loss of water supply, } \\
\text { Loss of electricity, } \\
\text { Damage to the land around the dwelling } \\
\text { Loss of water supply } \\
\text { Loss of electricity, } \\
\text { Broken windows, } \\
\text { Minor damage to the house }\end{array}$ \\
\hline St Peter & 3 out of 3 & Storm & Loss of electricity \\
\hline St Philip & 1 out of 2 & Storm & $\begin{array}{l}\text { Loss of water supply, } \\
\text { Loss of electricity }\end{array}$ \\
\hline St Thomas & 1 out of 2 & Storm &
\end{tabular}

\section{Discussion}

As demonstrated in Table 1, when it comes to Barbados achieving the Hyogo targets, the slowest progress is (and the lowest scores are) in the area of building regulatory framework implementation.

Many of the dwellings - whilst deemed safe - have been built based on the sense of responsibility of the contractors. DRR is more thought about when it comes to the construction of a public or a commercial building, since the process is more formal, and can therefore be more controlled. In addition, the clients worry about business continuity considerations, thus they are willing to invest in measures that can improve the potential of their business to be operational in the event of a hurricane (for instance). Structural measures are the main approach to DRR adopted in Barbados, with a larger focus on mitigating hurricanes than on any other natural hazard: typically building envelopes are able to withstand category 3 hurricanes (gusts of wind up to $130 \mathrm{mph}$ ); the focus is also on protecting windows by using either hurricane proof glass or installing shutters once a hurricane warning has been issued. For the larger commercial developments, the design of 
the building is often commissioned in the USA, where architects are more experienced with hurricane design.

"Well, if you use it [the draft of the Building Code] it's great, if you don't - oh well. It affects us if there is a crisis, when roofs blow off and houses fall down. We need to take note of all that [...] We try and encourage people: if you are building something, you know, go to the Town and Country Planning [authority responsible for the planning permissions], see what the codes are, but you can't always make people do that". (Government Ministry; emergency management)

However, financial savings often prevail and DRR measures are still not implemented to the extent they should be. This is a particular concern for the architects who are normally blamed for the poor quality of the building if the disaster strikes.

"Every client in Barbados knows about hurricanes. Whether they read too much into it, I am not sure. Maybe they rely on the design team for that" (Contractor).

The results of the survey indicate that the general public also understands the importance of stricter building regulations, however - until these are enforced - there is not really any incentive for them to conform to the existing regulations. On the contrary, compliance with the current draft of the Building Code will lead to a more expensive planning permit application process (as more detailed plans are required to be submitted); in addition, the construction of a dwelling would have to be performed by registered engineers and contractors, which will ultimately lead to higher upfront costs.

"Until there is a legal requirement, people are going to avoid it. Because economics is such, the budget is such that people will only do what they need to do. And even if it might mean loss of life or loss of property in the future, it is all about today, and not necessarily tomorrow” (Developer).

The interviews and the survey indicate that there is a belief that with the implementation of the Building Code, DRR could be more mainstreamed into construction practice. None of the interviewees explicitly stated the reasons for such a long delay with the Code's development and enforcement but it is clear that the extensive delay in its implementation effectively leads to ongoing difficulties in mainstreaming DRR principles into construction practice.

Nonetheless, there were a number of common issues raised by the respondents that could influence the extent to which the Code is ultimately adopted as well as the extent to which DRR will be integrated into development practices:

- Lack of capacity and coordination at the national level: DRR is not mainstreamed into the Code mainly due to the lack of capacity and human resources: for example, neither the DEM nor the Coastal Zone Management Unit were part of the technical committee and standing committees when the draft Code was put together. This also demonstrates the lack of awareness of disaster risks among the governmental bodies and their willingness to work together. The lack of cooperation is enhanced by the ineffective 
involvement of construction stockholders (as discussed in more detail in Chmutina and Bosher, 2014).

- Lack of understanding among the general public that the compliance with the Code (even in its draft form) will significantly improve the safety of the dwellings: Whilst the awareness about the hazards' occurrence is high, this does not translate into how people prepare for a disaster. The absence of a big event in the last couple of decades has led the public to believe that they are a 'God blessed nation' and 'nothing will happen'.

- A false belief that the enforcement of the Code will create more 'red tape': Interestingly, the planning application is separated from the building application, with the former being concerned about the outside of the building, and the latter being concerned about the inside of the building. Currently, it is not clear how the planning and building permit process will work when (and if) the Code becomes mandatory and building permits become separated from the planning permits and possibly will be scrutinised by different governmental institutions. This process creates duplication of work, which can lead to confusion among the applicants. However it is hoped that the process will be streamlined once the Code is mandatory.

- The focus of DRM efforts is on response and recovery activities. Emphasis on a more pre-emptive approach that embraces DRR could encourage the implementation of the Code as a basis for prevention and preparedness.

\subsection{Recommendations}

Whilst the revision of the Code and the incorporation of some of hazards in it is certainly an important step towards mainstreaming DRR and reducing the vulnerability of the Barbados building stock, it is clear that in order for the Code to be more effective, the following important issues should be addressed:

- Being up to date: it took 10 years for the previous draft of the Code to be updated, and could mainly be attributed to the willingness of an individual to see this task complete. The current version of the Code acknowledges the importance of climate change, however if the enforcement takes too long these impacts may be more severe thus making the current version of the Code less effective;

- Easy to use for local practitioners: currently the Code is written similar to the British Standards and thus relies on textual rather than visual messages. This motivates construction stakeholders to actually focus on the text and understand it. However, relatively high inputs from the more informal construction section (what may not have been formally technically trained) suggests that it may be more useful if the Code includes diagrams and drawings to support the text; thus encouraging adoption of new ideas by the informal construction practitioners. 
- Incorporating current understanding of risks (what are the threats and hazards, even if small?): despite the fact that the main hazards for Barbados are acknowledged in the Code, there is no indication of the risk these hazards (i.e. likelihood and potential impact) may impose on the built environment. In addition, it is not clear how the risk should and could be assessed (e.g. the use of open access multi-hazard risk maps), who should be responsible for conducting these risk assessments, and how the implementation of the Code in (construction) practice would reduce the identified risks.

- Enforcement and supervision of the Code implementation: this is the main and most critical issue. The creation of the new draft of the Building Code is certainly a step in the right direction, as it provides good guidance to those involved in construction, based on the specifics of the context in Barbados and the current international best practice. Nonetheless, until the code is mandatory, any 'compliance' with it will only be done voluntarily as the code is not yet legally 'enforceable'.

\section{Conclusions}

The Government of Barbados sees Disaster Risk Management as an important issue: this is demonstrated by their commitment to the Hyogo Framework and progress reporting, as well as by creation of government departments such as DEM and hosting a sub-regional focal point of the Caribbean Disaster Emergency Management Agency. Barbados is also a member of the Caribbean Catastrophe Risk Insurance Facility (CCRIF), and various government ministries are partners with such international donors as the United Nations Development Programme (UNDP) and Inter-American Development Bank (IADB). At the same time however the Barbados government creates challenges that could be avoided and - if resolved - could lead to the enhancement of DRR practices: a prime example of this is a lack of an enforced building code.

It has recently been highlighted by the GAR 2015 (UN 2015), that Disaster Risk Reduction activities need to move away from an approach constrained within disciplinary siloes dominated by emergency management and civil protection practitioners. The case of Barbados, despite good intentions and limited resources, is a good example of why it is essential to communicate better with a wider set of stakeholders including the general population and the construction sector. The awareness of the general population of natural hazards is high; however the complacency that is driven by the absence of a major disaster in the last couple of decades is also high.

In order to increase the compliance with the Code and mainstream DRR among the population, some of the following suggestions could be taken into account:

- Complementarity approach: if the end-users understand that the proposed measures are not only useful, for example, for improved thermal comfort, but can also be beneficial for improving the strength of the structure (thus increasing the safety of the 
dwelling), this would then increase the 'sell-ability' of the Code and general mainstreaming of DRR measures.

- Enforcement in place: in order to ensure correct implementation of the Code, it is critical to carry out an assessment of skill gaps, capacity, understanding and awareness of the importance of the building code. This can be performed in a form of an audit process and review consultations by the Building Standard Authority which will be responsible for the Code.

- Easy, clear and concise building and planning guidance: this is needed in cases when the competency of building industry is lower than expected; this guidance should be practical and easy to understand in order to be useful for the less skilled construction professionals, and maybe presented in a form of checklist. It could also be used by the homeowners who would then be able to 'supervise' the process of construction.

- Education: this should focus on construction industry training programmes and possibly related to specific hazards: for example, many of the engineers in Barbados undertake their training in the UK where earthquake hazards are not systematically included as part of the curriculum. Educational approaches can be achieved through continued professional development (CPD) type courses but also, ideally, incorporated into the professional training (i.e. undergraduate/ apprentice) of engineers, architects and planners (Bosher 2014).

To conclude, it is important to bear in mind that codes cannot be applied retrospectively, thus the existing stock will still remain unregulated; the mandatory enforcement of the code should thus be conducted as soon as possible. However, whilst the Code is not enforced, it is critical to engage with the general public in order for ensure that disaster risks can be considered at a household level and then hopefully reduced, as DRR is important not only for saving lives and protecting the built environment but also for ensuring the economic and political development of the country.

\section{References}

Barbados Statistical Service (2010). Population and housing census 2010. Available at: http://www.barstats.gov.bb/news/2010-population-and-housing-census-volume-1-nowavailable/ [accessed 3 March 2015].

Barbados National Standard Institution (2013). Barbados National Building Code 2013 BNS SP1:2013. St Michaels: Barbados.

Bosher L.S., (2014), 'Built-in resilience’ through Disaster Risk Reduction: Operational issues’, Building Research and Information, 42 (2), 240-254

Caribbean Disaster Emergency Response Agency (2004). Institutional review of the disaster management mechanism in Barbados. Available at: 
http://www.pacificdisaster.net/pdnadmin/data/original/institutional_review_dm_mechanism_ agency.pdf [accessed 3 March 2015].

Caribsave Partnership (2012), “CARIBSAVE climate change risk profile for Barbados”, summary document, available at:

http://www.caribsave.org/assets/files/CCCRA\%20Final\%20Documents/FINAL\%20Summar y\%20Document\%20CCCRA\%20-\%20Barbados.pdf [accessed 3 March 2015].

Chmutina, K. and Bosher, L. (2014). Construction in Barbados: keeping natural hazards in mind? Disaster Prevention and Management. 23 (2), 175-196.

Collymore, J. (1992). Planning to reduce the socio-economic impacts of natural hazards on Caribbean society. The Journal of the Geological Society of Jamaica. 2, 88-97.

Collymore, J. (2011), Disaster management in the Caribbean: perspective on institutional capacity reform and development. Environmental Hazards. 10 (1), 6-22.

De Weerd-Nederhof, P.C. (2001). Qualitative case study research. The case of a PhD research project on organising and managing new product development systems. Management Decision. 39 (7), 513 - 38.

Department of Emergency Management (2013). Barbados: National progress report on the implementation of the Hyogo Framework for Action (2011-2013). Available at: http://www.preventionweb.net/english/hyogo/national/reports/v.php?id=31056\&pid:183 [accessed 3 March 2015].

Department of Emergency Management (2014). Available at: http://dem.gov.bb/index.php/about/historical [accessed 3 March 2015].

Eisenhardt, K.M. (1989). Building theories from case study research. The Academy of Management Review. 14 (4), 532-50.

Griffin, F. (2007), "Vulnerability to Natural Disasters”, Speech prepared for 18th Meeting of International cooperation directors of Latin America and the Caribbean, Caracas, Venezuela, 17-18 September, available at:

http://www.sela.org/DB/ricsela/EDOCS/SRed/2007/09/T023600002616-0-

Vulnerability_to_Natural_Disasters.pdf [accessed 3 March 2015].

King, L.W. (2014). The code of Hammurabi (translated by). Netlancers Inc., Sunnyvale.

Hinds, K. and Spence, B. (2006), Caribbean Disaster Management project: Barbados. Examples of natural disaster mitigation in small island developing states. 12, 15-28. Available at: http://tcdc2.undp.org/GSSDAcademy/SIE/Docs/Vol12/1Caribbean.pdf [accessed 3 March 2015].

Howitt, D. and Cramer, D. (2011). Introduction to Research Methods. Prentice Hall: UK. 
Laframboise, N. and Acevedo, S. (2014). Man versus Mother Nature. Finance and Development, March, 44-47.

Lofland, J. and Lofland, L. (1995). Analyzing Social Settings: A Guide to Qualitative Observation and Analysis. Wadsworth Publishing: USA.

Organisation of American States (2011). CELP profile: Barbados. Available at: http://www.oas.org/dsd/EnvironmentLaw/CaribbeanLegislationProject/Profiles/BarbadosFIN AL.pdf [accessed 3 March 2015].

Prevatt, D.O., Dupigny-Giroux, L., Masters, F. (2010). Engineering Perspectives on Reducing Hurricane Damage to Housing in CARICOM Caribbean Islands. Natural Hazards Review. 11(4), 140-150.

Pulwarty, R.S., Nurse, L.A. and Trotz, U.O. (2010). Caribbean islands in a changing climate. Environment, November- December, available at: http://www.environmentmagazine.org/Archives/Back\%20Issues/NovemberDecember\%202010/caribbean-islands-full.html [accessed 3 March 2015].

Rasmussen, T. (2006). Natural Disasters and Their Macroeconomic Implications. In: Sahay, R., Robinson, D and Cashin, P. (eds.), The Caribbean: From Vulnerability to Sustained Growth. Washington: International Monetary Fund, USA, 181-205.

Sarmiento, J.P. and Hoberman, G. (2011). Disaster Risk Management in the Caribbean: Evidence from Barbados, Dominican Republic, Jamaica and Trinidad and Tobago. Available at: http://digitalcommons.fiu.edu/whemsac/28/ [accessed 3 March 2015].

Statistical Service Centre (2001). Approaches to the analysis of survey data. The University of Reading. Available at:

http://www.reading.ac.uk/ssc/n/resources/Docs/Approaches_to_the_analysis_of_survey_data. pdf [accessed 3 March 2015].

The Caribbean Disaster Emergency Response Agency (CDERA) (2003), "Status of hazard maps vulnerability assessment and digital maps”, Barbados country report, available at: http://www.eird.org/wikien/images/Hazard_maps_vulnerability_assesments_Barbados.pdf [accessed 3 March 2015].

The Government of Barbados (2005), "Barbados National Assessment Report on the Implementation of the Barbados Plan of Action", available at:

http://czmedia.org/uploads/Barbados_NAR_on_the_Implementation_of_the_BPOA.pdf [accessed 3 March 2015].

The Government of Barbados (2006). The Emergency Management Act 2006.

Thomas, J. (2013). Barbados: national progress report on the implementation of the Hyogo Framework for Action (2011-2013). Available at:

http://www.preventionweb.net/files/31056_brb_NationalHFAprogress_2011-13.pdf

[accessed 3 March 2015]. 
United Nations, (2015). Global Assessment Report 2015, UNISDR, Geneva

United Nations (2013). Global Assessment Report 2013. Available at:

http://www.preventionweb.net/english/hyogo/gar/2013/en/gar-pdf/GAR2013_EN.pdf [accessed 3 March 2015].

UNDP (2013). Human development report: Barbados. Available at:

http://hdrstats.undp.org/en/countries/profiles/BRB.html [accessed 3 March 2015].

Worldmark Encyclopaedia of Nations (2007), “Barbados”, available at:

http://www.encyclopedia.com/topic/Barbados.aspx [accessed 3 March 2015].

Yin, R.K. (1994), “Case study research: design and methods”, Sage Thousand Oaks, UK.

Zhou, Q., Li, J.Y. and Zhao, J.B. (2003). Study on index system of assessment of public disaster perception in the Western China. Chinese geographical science. 13 (3), 284-88. 